\title{
Gender Stereotypes and Self-Efficacy as Determinants of the Glass Ceiling Effect: A Study of Female Civil Servants in Central Java
}

\author{
Salsabila Firdausia ${ }^{1}$, Munawir Yusuf ${ }^{2}$, Fadjri Kirana Anggarani ${ }^{3}$ \\ 1,2,3Faculty of Psychology, Universitas Sebelas Maret
}

Submitted 21 February 2019 Accepted 18 June 2019 Published 20 April 2020

\begin{abstract}
Glass ceiling refers to the obstruction of opportunities for female employees to get promoted to higher positions, despite being qualified and having achievements, due to gender discrimination. This study aimed to identify the relationship between gender stereotypes and self-efficacy with the glass ceiling phenomenon experienced by female civil servants in Central Java. Sixty female civil servants were involved as samples. This study used three instruments: glass ceiling scale $(\alpha=0.855)$, gender stereotypes scale $(\alpha=$ $0.933)$, and self-efficacy scale $(\alpha=0.879)$. The data was processed using linear regression analysis. The findings revealed that there was a strong correlation $(\mathrm{r}=0.803)$ between gender stereotypes $\left(\beta_{1}=0.377\right)$ and self-efficacy $\left(\beta_{2}=-0.431\right)$ with the glass ceiling phenomenon experienced by female civil servants in Central Java.
\end{abstract}

Keywords: glass ceiling; gender stereotypes; self-efficacy

According to a survey of female representation in civil service by the United Nations Development Programme (UNDP) (Bari, 2010), the number of female civil servants decreases in each echelon. Female representation in Echelon $\mathrm{I}$ is recorded to be under $9 \%$. The lack of female representation in structural positions is also found in the Agency for Regional Development (Bappeda) in the province of Central Java. Out of 29 seats available, only eight seats are occupied by women. A preliminary study was conducted by interviewing a female civil servant with a general functional position in Central Java Bappeda. The study showed that, even though the number of women who are qualified to get into structural positions (Echelon IIIlb) is higher

\footnotetext{
${ }^{1}$ Address for corespondence:

Sfirdausia7@gmail.com
}

than men, the structural positions are still dominated by the latter.

According to the records held by Statistics Indonesia (BPS) in 2017, female civil servants amount to $48.6 \%$ of the total number of civil servants. This large representation, according to the Engineering Career Center Universitas Gadjah Mada (ECC, 2014), is due to several reasons (e.g., insurance, security from work termination, clarity of career). There are four structural levels in the civil servant career known as echelons, each with different functions and authority.

The empiric case above proved the existence of glass ceiling or gender inequality in higher positions of an organization which put women on a disadvantage (Mathis \& Jackson, 2001). Women are obliged to perform better than required to get promoted, but despite 
having the competency, women will face work obstruction and work stress. Work stress could cause role conflict between women's role at work and at home $(\mathrm{Li} \&$ Wang Leung, 2001). This situation could lead to them giving up their job (Kephart \& Schumacher, 2005).

The glass ceiling phenomenon in public sectors is significantly driven by several factors, such as organizational culture, homophily, workplace network, discrimination (Purcell, MacArthur, \& Samblanet, 2010) and gender stereotypes $(\mathrm{F}=0.003, \mathrm{p}<0.05)$ (Purcell et al., 2010; Pradipta, 2015; Shabbir, Shakeel, \& Zubair, 2017). Gender stereotypes cause a belief of differences between the nature of a man and that of a woman. Organizations tend to see women as less qualified to be a leader (Falk, Research, \& Grizard, 2003). This form of stereotype causes women to think of themselves as less professional and more emotional in facing a problem compared to men (Pradipta, 2015). They add that women are believed to pick their family matters over the organizational matters. Those reasons make women lose enthusiasm to succeed in their career and perform less at work (Soleymanpour Omran, Alizadeh, \& Esmaeeli, 2019).

The decreasing performance at work should not happen if the women who face a glass ceiling had high self-efficacy (Bolat, Tamer; Bolat, Oya Inci; Kili, 2011). Individuals with self-efficacy will set higher goals and perform better in reaching their target (Bandura, 1998). In reverse, individuals with low self-efficacy will show worse performance and are prone to turn-over when meeting obstacles (Cunningham, 2003) and lose the courage to accept a big responsibility (Kılıç, 2017).

The explanation above shows that gender stereotypes and self-efficacy have significant effects against the glass ceiling
(Pradipta, 2015). Adverse effects of glass ceiling which have been a focus of studies for a long time show the urgency of studying the problem through the factors, such as gender stereotypes and selfefficacy. Therefore, this research aims to identify the relationship between gender stereotypes and self-efficacy with the glass ceiling phenomenon experienced by female civil servants in Central Java.

\section{Method}

The participants of this research were 60 female civil servants who worked at Bappeda Central Java. Respondents were recruited using purposive sampling method with the following inclusive criteria: Echelon IIIb or higher and had at least a bachelor's degree. Based on the criteria, 60 respondents were recruited as participants.

This study used three scales: (1) Glass ceiling scale (19 items; Cronbach's alpha = 0.855), developed from the glass ceiling concept by Cotter, Hermsen, Ovadia, \& Vanneman (2007) which consists of four aspects. The aspects are gender inequality irrelevant to work characteristics, gender discrimination in higher positions, gender discriminations in getting higher positions, and awareness of the adverse effects of glass ceiling. (2) Gender stereotypes scale (32 items; Cronbach's alpha $=0.933$ ), developed from the gender stereotypes concept by Firin (2004) which consists of four aspects: personality and trait, social role and position, physical appearance, role in the family. (3) Self-efficacy scale (19 items; Cronbach's alpha $=0.879)$ modified from a scale by Tetiana (2016) based on the self-efficacy concept by Bandura (1998) which consists of level, strength, and generality. 


\section{Results}

Table 1 shows that there were 60 respondents $(\mathrm{N})$ involved in this research. No missing data were found. The empirical data from the glass ceiling scale reveals a minimum score of 38 , a maximum score of $68, \mathrm{M}=56.85$, and $\mathrm{SD}=7.058$. The gender stereotypes scale scored a minimum score of 80 , a maximum score of $106, \mathrm{M}=93.16$, and $\mathrm{SD}=8.264$. Lastly, the self-efficacy scale has a minimum score of
39 , a maximum score of $65, \mathrm{M}=49.12$, and $\mathrm{SD}=7.104$.

Table 2 depicts that most female civil servants had high glass ceiling level $(56.6 \%)$, a middle gender stereotype level $(53.3 \%)$, and a middle self-efficacy level (83.3\%). Test result showed that the hypothesis of this research was accepted, namely that both gender stereotype and self-efficacy is correlated with glass ceiling.

Table 1.

Descriptive Data

\begin{tabular}{|c|c|c|c|c|}
\hline & & Glass Ceiling & Gender Stereotypes & Self-Efficacy \\
\hline \multirow{2}{*}{$\mathrm{N}$} & Valid & 60 & 60 & 60 \\
\hline & Missing & 0 & 0 & 0 \\
\hline \multicolumn{2}{|c|}{ Std. Error of Mean } & .91127 & 1.06675 & .91722 \\
\hline \multicolumn{2}{|c|}{ Std. Deviation } & 7.05865 & 8.26298 & 7.10476 \\
\hline \multicolumn{2}{|c|}{ Variance } & 49.825 & 68.277 & 50.478 \\
\hline \multicolumn{2}{|c|}{ Range } & 30.00 & 26.00 & 26.00 \\
\hline \multicolumn{2}{|c|}{ Minimum } & 38.00 & 80.00 & 39.00 \\
\hline \multicolumn{2}{|c|}{ Maximum } & 68.00 & 106.00 & 65.00 \\
\hline
\end{tabular}

Table 2.

Descriptive Statistics

\begin{tabular}{ccccc}
\hline Variables & Categories & Norms & Respondents & Percentage (\%) \\
\hline \multirow{3}{*}{ Glass Ceiling } & Low & $19 \leq \mathrm{X}<38$ & - & - \\
& Middle & $38 \leq \mathrm{X}<57$ & 26 & $43.3 \%$ \\
Gender & High & $57 \leq \mathrm{X}<76$ & 34 & $56.6 \%$ \\
Stereotype & Low & $32 \leq \mathrm{X}<64$ & - & - \\
& Middle & $64 \leq \mathrm{X}<96$ & 32 & $53.3 \%$ \\
Self-Efficacy & High & $96 \leq \mathrm{X}<128$ & 28 & $46.6 \%$ \\
& Low & $19 \leq \mathrm{X}<38$ & - & - \\
& Middle & $38 \leq \mathrm{X}<57$ & 50 & $83.3 \%$ \\
& High & $57 \leq \mathrm{X}<76$ & 10 & $16.6 \%$ \\
\hline
\end{tabular}

Table 3.

F-Test

\begin{tabular}{ccccccc}
\hline \multicolumn{1}{c}{ Model } & Sum of Squares & df & Mean Square & F & Sig. \\
\hline \multirow{2}{*}{1} & Regression & 1894.770 & 2 & 947.385 & $\mathbf{5 1 . 6 8 1}$ & $\mathbf{. 0 0 0}^{\mathbf{b}}$ \\
& Residual & 1044.880 & 57 & 18.331 & & \\
& Total & 2939.650 & 59 & & & \\
\hline
\end{tabular}

aDependent Variable: Glass Ceiling b.Predictors: (Constant), Self-Efficacy, Gender Stereotypes 
The value of $\mathrm{F}_{\text {calculated }}$ is higher than the $\mathrm{F}_{\text {tabulated, }} 51.681>3.16\left(\mathrm{~F}_{\text {calculated }}>\mathrm{F}_{\text {tabulated }}\right)$ or $\mathrm{F}(2,57)=51.681, \mathrm{p}=0.000$ which meant there was a significant correlation between gender stereotypes and self-efficacy with glass ceiling on female civil servants in Bappeda Central Java.

Table 4 shows that the value of $\mathrm{R}$ is 0.803. It is justifiable to conclude that there is a strong correlation between the predictors (i.e., gender stereotypes, selfefficacy) and dependent variable (i.e., glass ceiling) of female civil servants in Bappeda Central Java.

Based on Table 4, the value of $R$ Square is 0.645 . This indicates that gender stereotypes and self-efficacy could explain $64.5 \%$ of the glass ceiling experienced by female civil servants. The remaining $35.5 \%$ is explained by other factors outside of the scope of this research.

Table 5 shows significance with the value of $0 ., 000(p<0.05)$ and correlation coefficient between self-efficacy and glass ceiling of -0.735 . Pearson's correlation test result concludes that there is a significant negative correlation between self-efficacy and glass ceiling. It can be understood that gender stereotypes affect glass ceiling of female civil servants in Bappeda Central Java.

This research found that gender stereotypes contributes $32.62 \%$ in explaining glass ceiling, while self-efficacy has an effective contribution of $31.89 \%$ in explaining glass ceiling.

\section{Discussion}

Based on the findings, it is justified to conclude that the research hypothesis was accepted, namely that there was a significant correlation between gender stereotypes and self-efficacy with glass ceiling experienced by female civil servants in Bappeda Central Java. In explaining glass ceiling, gender stereotypes plays a critical insight to those

Table 4.

Multiple Correlation Analysis and Determination Analysis Result

\begin{tabular}{cccccc}
\hline Model & R & R Square & Adjusted R Square & SE & Durbin-Watson \\
\hline 1 & $.803^{\mathrm{a}}$ & $\mathbf{. 6 4 5}$ & .632 & 4.28150 & 2.192 \\
\hline
\end{tabular}

aPredictors: (Constant), Self-Efficacy, Gender Stereotype bDependent Variable: Glass Ceiling

Table 5.

Pearson's Correlation Test

\begin{tabular}{ccccc}
\hline & Glass Ceiling & Gender Stereotypes & Self-Efficacy \\
\hline \multirow{4}{*}{ Pearson's Correlation Stereotype Gender } & 1.000 & .738 & -.735 \\
& Glass Ceiling & .738 & 1.000 & -.683 \\
& Self-Efficacy & -.735 & -.683 & 1.000 \\
\multirow{4}{*}{ Sig. (1-tailed) } & Glass Ceiling &. & .000 & .000 \\
& Stereotype Gender & .000 &. & .000 \\
& Self-Efficacy & .000 & .000 &. \\
$\mathrm{~N}$ & Glass Ceiling & 60 & 60 & 60 \\
& Stereotype Gender & 60 & 60 & 60 \\
& Self-Efficacy & 60 & 60 & 60 \\
\hline
\end{tabular}


who hope to reach higher position in an organization. Most individuals believe that they must possess masculine traits to achieve top positions. These traits include being quick to adapt in challenging situations (Rogers et al., 2006), assertive, dominant, and independent (Cann \& Siegfried, 1990). Women are often viewed as having traits that are unsuitable for a lead position (e.g., passiveness and dependence) (Conway \& Vartanian, 2000).

The explanation above shows that female civil servants in Bappeda Central Java with high level of gender stereotypes tend to categorize the traits that a woman should have. The gender stereotype leads to the obstruction in women's career growth due to having inaccurate views about what type of person is considered as suitable to own high positions. In reverse, female civil servants in Bappeda Central Java with low level of gender stereotypes had more courage to break free from the societal gender norms. As a result, they became more assertive when dealing with organizational matters.

Female civil servants with high selfefficacy could handle glass ceiling with more ease. This is because they have more faith in their ability to stand up in situations that hinder them from reaching higher positions. In reverse, female civil servants with low self-efficacy tend to feel anxious when their project does not work as planned. Low self-efficacy can bring an individual into a powerless state, making it more difficult for them to adapt to organizational expectations. Low selfesteem could cause stress and hinder individuals from reaching maximum work performance (Frank, 2013).

This study found that there was a significant positive correlation between gender stereotypes and glass ceiling. This research shows similar result to a study by
Shabbir et al. (2017) which discovered that gender stereotypes is one of the factors that causes glass ceiling. Gender stereotypes exists and grows in society from socialization during childhood and teenage years by parents, teachers, friends, and mass media (Vroom \& Jago, 1978). Mass media has a profound impact on how people judge women's abilities in social order (Bligh, Schlehofer, Casad, \& Gaffney, 2012). From a young age, women are taught that their welfare and success depend on their behaviors (e.g., being polite, speaking softly, being obedient, and being relationship-oriented.

Gender stereotypes affect how individuals behave, making women unconsciously focus more on being attractive, warm, and supportive rather than aggressive. Women prefer collaborating to competing, listening to talking, and are more comfortable to use relationships in reaching their goals rather than showing their skills (Vroom \& Jago, 1978). Individuals with high gender stereotypes tend to think that they are fighting against the norms as women if they have to work in high position, leading them to face hard situation to improve their career.

This study also found that there was a significant negative relationship between self-efficacy and glass ceiling. In other words, self-efficacy is one of the factors that contribute to the occurrence of glass ceiling. Self-efficacy verifies how certain every individuals making effort to reach the result that they are hoping. Women with high self-efficacy could perform well at work and handle glass ceiling in a much better way (Shields, 2005).

Women with low self-efficacy will show unsatisfying work performance and would be in despair when facing an obstacle. The inability for women to reach high positions is caused by the lack of trust 
in their own self to perform the tasks that require high mobility (Shields, 2005). Women with high level of diligence and a bigger goal would be able to face gender discrimination at work place (Britner \& Pajares, 2006).

\section{Conclusion}

This research succeeded in finding that there was a significant relationship between gender stereotypes and selfefficacy with glass ceiling on female civil servants in Bappeda Central Java $(\mathrm{F}=$ 51.681; $\mathrm{p}=0.000)$. There is a positive and significant correlation between gender stereotypes and glass ceiling on female civil servants in Bappeda Central Java ( $\beta_{1}=$ 0.377; $\mathrm{p}=0.000)$. This research also found that there was a negative and significant correlation between self-efficacy and glass ceiling on female civil servants in Bappeda Central Java $\left(\beta_{2}=-0.431 ; p=0.000\right)$.

\section{Suggestion}

Overall, most of the female civil servants in Bappeda Central Java were categorized as women with high level of glass ceiling. To reduce and anticipate glass ceiling on female civil servants, self-efficacy training for women is needed. The existence of a female leader as a role model and opportunities for female civil servants to receive bigger responsibility will train the competence of female civil servants so they can work in higher positions. It is important to note for future researchers that other factors should be used to explain glass ceiling. Current researcher suggests to dig deeper about the power and distinctive characteristics that women need to work in high positions.

\section{References}

Rogers, A. D., Sintek, E., Tye, M., Krauss, A., DeArmond, S., \& Chen, P. Y. (2006). Age and gender stereotypes: New challenges in a changing workplace and workforce. Journal of Applied Social Psychology, 2184-2214. doi: 10.1111/j.0021-9029.2006.00100.x

Bandura, A. (1998). Bandura 1994 EHB. 4(1994), 71-81.

Bari, F. (2010). Partisipasi perempuan dalam politik dan pemerintahan. Jakarta: United Nations.

Bligh, M. C., Schlehofer, M. M., Casad, B. J., \& Gaffney, A. M. (2012). Competent enough, but would you vote for her? Gender stereotypes and media influences on perceptions of women politicians. Journal of Applied Social Psychology, 42(3), 560-597. doi: 10.1111/j.1559-1816.2011.00781.x

Bolat, T., Bolat, O. I., \& Kili? T. (2011). Career self-efficacy and glass ceiling: Moderating effect of work-related masculinity values. Retrieved from http://connection.ebscohost.com/c/arti cles/59973578/career-self-efficacyglass-ceiling-moderating-effect-workrelated-masculinity-values

Badan Pusat Statistik (BPS). (2017). Tingkat partisipasi angkatan kerja. Retrieved from bps.go.id website: https://www.bps.go.id/index.php/brs/ $\underline{1377}$

Britner, S. L., \& Pajares, F. (2006). Sources of science self-efficacy beliefs of middle school students. Journal of Research in Science Teaching, 43(5), 485499. doi: 10.1002/tea.20131

Cann, A., \& Siegfried, W. D. (1990). Gender stereotypes and dimensions of effective, 23, 413-419. 
Conway, M., \& Vartanian, L. R. (2000). A status account of gender stereotypes: Beyond communality and agency. Sex Roles, 43(3-4), 181-199. doi: 10.1023/A:1007076813819

Cotter, D. A., Hermsen, J. M., Ovadia, S., \& Vanneman, R. (2007). The glass ceiling effect. Social Forces, 80(2), 655-681. doi: $\underline{10.1353 / \text { sof.2001.0091 }}$

Cunningham, G. B. (2003). Already aware of the glass ceiling: Race-related effects of perceived opportunity on the career choices of college athletes. Journal of African American Studies, 7(1), 57-71. doi: $\underline{10.1007 / \mathrm{s} 12111-003-1003-8}$

ECC. (2014). Sebanyak 38,2\% Perempuan pilih Jadi ASN. Retrieved from career.web.id website:

https://www.careernews.web.id.issues Lview/2783-Sebanyak-3872-Perempuan -Pilih-Jadi-ASN

Falk, E., Research, W., \& Grizard, E. (2003). The glass ceiling persists: The 3rd Annual APPC report on women leaders in communication companies. (March).

Firin, M. (2004). Pengaruh simbol lelaki, perempuan, dan toga serta pemaknaannya terhadap sikap stereotip gender. (Unpublished master's thesis). Faculty of Psychology, Universitas Gadjah Mada, Yogyakarta.

Frank, C. P. (2013). The development of academic advising programs. NACADA Journal, 8(1), 11-28. doi: $\underline{10.12930 / 0271-9517-8.1 .11}$

Kephart, P., \& Schumacher, L. (2005). Has the "glass ceiling" cracked? An exploration of women entrepreneurship. Journal of Leadership $\mathcal{E}$ Organizational Studies, 12(1), 2-15. doi: $\underline{10.1177 / 107179190501200102}$

Kılıç, T. (2017). Relationship between glass ceiling syndrome and self-efficacy: in health sector. European Journal of
Multidisciplinary Studies, 4(3), 84. doi: 10.26417/ejms.v4i3.p84-87

Li, L., \& Wang Leung, R. (2001). Female managers in Asian hotels: Profile and career challenges. International Journal of Contemporary Hospitality Management, 13(4), 189-196. doi: $\underline{10.1108 / 09596110110389511}$

Mathis, R \& Jackson, J. (2001). Manajemen sumber daya manusia. Jakarta: Salemba Empat.

Pradipta, N. (2015). Analisis faktor-faktor yang berpengaruh pada glass ceiling karyawan perempuan di industri perhotelan Yogyakarta. (Unpublished master's thesis). Faculty of Economy and Business, Universitas Gadjah Mada, Yogyakarta.

Purcell, D., MacArthur, K. R., \& Samblanet, S. (2010). Gender and the glass ceiling at work. Sociology Compass, 4(9), 705-717. doi: 10.1111/j.1751-9020.2010.00304.x

Shabbir, H., Shakeel, M. A., \& Zubair, R. A. (2017). Gender stereotype, glass ceiling and women's career advancement: An empirical study in service sector of Pakistan. City University Research Journal, 236-246.

Shields, S. A. (2005). The politics of emotion in everyday life: "appropriate" emotion and claims on identity. Review of General Psychology, 9(1), 3-15. doi: 10.1037/1089-2680.9.1.3

Soleymanpour Omran, M., Alizadeh, H., \& Esmaeeli, B. (2019). The analysis of glass ceiling phenomenon in the promotion of women's abilities in organizations. International Journal of Organizational Leadership, 4(3), 315-323. doi: $\underline{10.33844 / \text { ijol.2015.60323 }}$

Tetiana, T. (2016). Hubungan goal setting dan efikasi diri akademik dengan kepribadian sebagai moderator. 
(Unpublished master's thesis). Faculty of Psychology, Universitas Gadjah Mada, Yogyakarta.

Vroom, V. H., \& Jago, A. G. (1978). On the validity of the Vroom-Yetton model. Journal of Applied Psychology, 63(2), 151-162. doi: 10.1037/0021$\underline{9010.63 .2 .151}$ 